\title{
Appendix: \\ An Anthology of Miners' Poems
}

Work Poems

A Colorado Miner's Fourth

Oh stranger, this is a great day on this part of the earth -

it's "Independence Day" of ours, which gave our nation birth,

When our patriots assembled and declared, "It shall not be,

We'll stand no more oppression; our country shall be free."

While from the call of duty these miners will not shirk,

This is the one day in the year on which they will not work.

I never worked on but one fourth, and that one was the last

Fourth of July I'll ever mine, where'er my lot be cast,

'Twas at a place called Goldfield in the county of Pinal,

Way down in Arizona, I was working with a "pal,"

There were nothing doing on this fourth, there was no place to go,

So we decided we would work and try to save some "dough."

The day it passed off quickly, we were young then, full of life, 
We've since had many ups and downs in this hard world of strife.

So when the shades of evening fell we thought it was our right

With other kindred spirits there, to celebrate that night.

The boys had scarcely settled down to have a quiet time,

With refreshments by the bottle, and several different kinds.

When in rushed old Riel Morse, his face as pale as death,

And says: "Come boys, get out of here!" when he could catch

his breath.

"For that old stope has caved in, clear down to the 2;

"Come get your digging clothes on, boys, for there'll be need of you."

If Stevens was back in his drift, we knew there was some hope.

His orders were, that very day, "not to go through that stope."

We jumped into our harness, for the mine we made a dash, And there we found Bolitho, for he had heard the crash.

Our foreman in the mine was he, and right here let me say,

He was a good one, stranger, he sleeps beneath the clay,

Near the new shaft he was standing, and with steady voice and slow,

Says he: "Now I want one of you to go with me below.

"We'll go down to the 7; I think the shaft's all right,

"To see if Jimmy Lee is safe - he's working there to-night."

On the bucket there with Billy stepped the Kid without a word. 
They found Lee on the 7, he knew not what occurred.

To the surface on the bucket, and back down to the 3,

They went, to find the quickest way to set poor Stevens free.

But that old stope was working - you could hear the timbers pop -

So Billy thought it safer to sink down from the top.

He picked out four of us at once to work on that night shift.

We started through the old cave there to tap poor Jimmy's drift.

Then Billy called up all the boys, and these words to them said:

"I'll want you in the morning, boys, now you can go to bed.

"I want you all to stay in camp, we will need all of you,

"For I'll work every man I can to carry that shaft through."

But every man was anxious, each one in the crew,

With strong hands and willing hearts to help on this rescue.

While Stevens, he was working too, we heard him digging in

To reach a little air-shaft which was not far from him.

But the ground was dry as powder, like sand it ran in fast,

And, with no light or timbers, he gave it up at last.

The time they made on this first shaft was pretty hard to beat;

It had taken just three days to sink it fifty feet.

But there we struck some timbers which came from that old stope.

We could not drive our spile in, and with them could not cope.

The morning of the 8th, then, Billy says: "We'll have to quit 
And start a shaft thro' solid land; I know we can sink it."

The place where they then started in was right above Jim's drift,

And a small stope, some eighteen feet there, gave them quite a

lift.

Two rows of stulls they threw in there and lagged up good and

tight,

And how those miners made the "muck" fly was a pretty sight.

For they all worked like demons; there were many feet to drive,

We never thought to find poor Jimmy Stevens there alive.

Not one man in ten thousand could stand it, do you think?

Entombed alive for thirteen days, and without food or drink.

But Jimmy bore up bravely, and when the boys would drill,

They'd rap upon the foot-wall and he'd rap back with a will.

And this would cheer the boys up, and they'd dig in like a Turk.

They never needed any boss to make them do their work.

One hundred six and twenty feet that new shaft had to go.

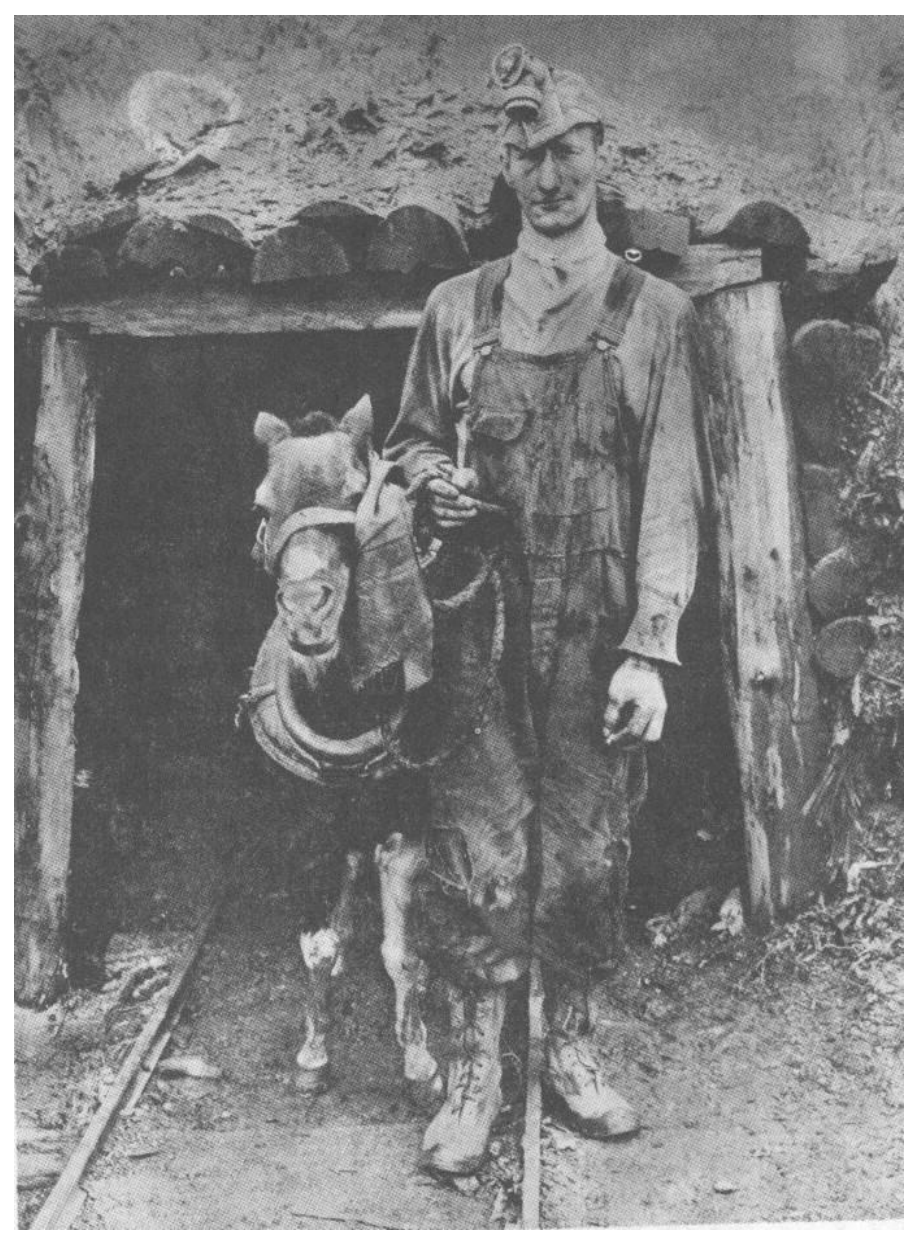

Before they made connection with Jimmy's drift below.

The morning of the 17 th the sun rose bright and fair,

You'd see by groups of miners who were scattered here and there.

By subdued voices, anxious faces, each one felt the strain,

And hoped that all their gallant efforts had not been in vain. 
The "graveyard" shift had just come up, they knew the end was

near,

They knew that Stevens was alive, but would his mind be clear?

The morning shift had been on thirty minutes, or about,

When up the shaft came ringing a glad and joyful shout:

"We've reached him, boys, he is all right, we have just now broke thro'!"

Then down the shaft a doctor went, to tell them what to do.

And when the doctor looked at Jim, he says: "Why he's all right,

"But we will keep him here a while, the sunlight is too bright."

In Colorado, all this time, their loving hearts did yearn,

His wife and little children, praying for his safe return.

For Jimmy, he had told me: "On the 15th I'll go home,

"To see my wife and family, for I'm too old to roam."

There, with aching heart, she waited; she knew about the cave,

How hard at work his comrades were, her husband's life to save.

How proud those happy miners were when they sent the news

that night

To his wife in Central City: "Your Jimmy's safe, all right!"

The people down in Mesa, "they're Mormons," some folks say,

The miners won't forget them if they live till Judgment Day;

For when they heard the story of these miners' brave rescue

That Stevens was all right once more, they knew just what to do. 
They commenced to cooking chickens, cakes and pies, and

brought the band

And with their wives and daughters came to shake them by the hand.

The way those hard-worked miners the whole bakery did take,

They say it was no "cake-walk," but walking into cake.

And how they stowed those "gumys" away, it surely was a fright.

They danced and ate, and ate and danced, till early morning light

While Jimmy Stevens, so they say, gained seven pounds that

night

"'Twas time for one to pick up some, who's forty-eight pounds

light."

The good people from that valley, to them it was a treat

To see those chickens disappear and watch those miners eat.

They showed a Christian spirit, true, and when they bade adieu, invited every miner there to come and see them, too.

And when with hearts and baskets light they journeyed home

again

They left kind memories of them which always will remain.

Up home in Central City, when Jimmy stepped down off the train With a band his friends had gathered there to welcome him again The meeting with his loving wife who found him safe from harm. His joy to see his little ones, and clasp them in his arms, 
This picture is too sacred, pard; I'll draw the curtain here,

For scenes like this are apt to start from me a pensive tear.

And there I fain would leave him now, alive and doing well.

But alas! poor Jimmy's story, the sad truth I must tell:

Far up in Colorado's hills he sleeps beneath the sod,

Caught in a cave in a mine there, he went to meet his God.

So, stranger, when each glorious Fourth of July rolls around,

I think of Jimmy Stevens, and stay from under ground.

Joe

R.

Lazure, "Hobo Miner"

\section{TheWorker}

I have broken my hands on your granite,

I have broken my strength on your steel;

I have sweated through years for your pleasure,

I have worked like a slave for your weal;

And what is the wage you have paid me?

You masters and drivers of men.

Enough so I come in my hunger

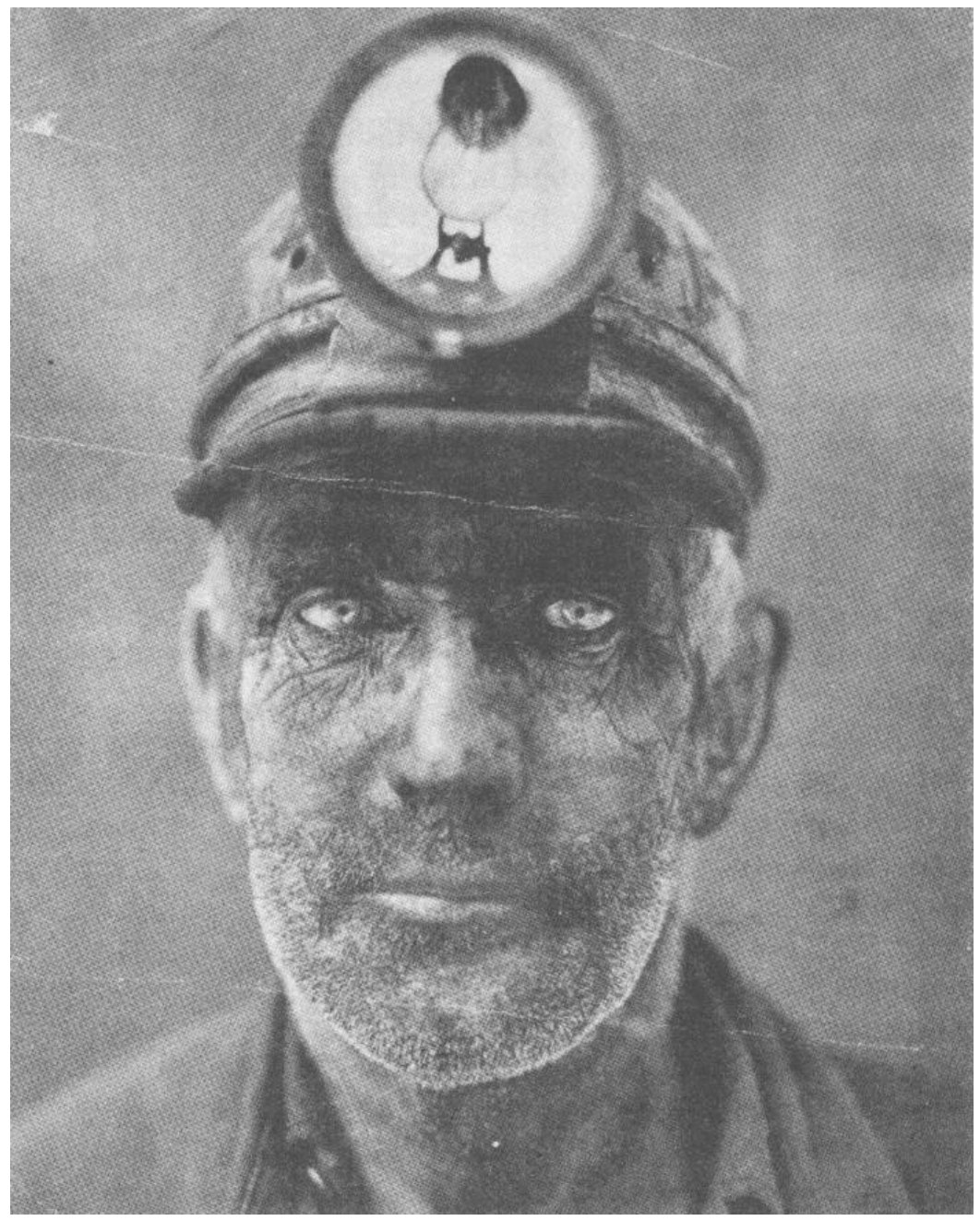

COAL MINER, 1944

To beg for more labor again!

I have given my manhood to serve you,

I have given my gladness and youth,

You have used me, and spent me, and crushed me 
And thrown me aside without ruth;

You have shut my eyes off from the sunlight -

My lungs from the untainted air,

You have housed me in horrible places

Surrounded by squalor and care.

I have built you the world in its beauty,

I have brought you the glory and spoil;

You have blighted my sons and my daughters,

You have scourged me again to my toil,

Yet I suffer it all in my patience,

For, somehow, I dimly have known

That someday the worker will conquer

In a world that was meant for his own.

\section{Berton Braley}

\section{Poems of Praise}

\section{The Man Behind the Pick}

There has been all kinds of gush about the man who is "behind" -

And the man behind the cannon has been toasted, wined and dined.

There's the man behind the musket and the man behind the fence; And the man behind his whiskers, and the man behind his rents, And the man behind his plow beam, and the man behind the hoe; 
And the man behind the ballot and the man behind the dough;

And the man behind the jimmy, and the man behind the bars;

And the Johnny that goes snooping on the stage behind the

"stars";

And the man behind the kisser, and the man behind the fist;

And the girl behind the man behind the gun is on the list;

But they've missed one honest fellow, and I'm raising of a kick,

That they didn't make a mention of the man behind the pick.

Up the rugged mountain side, a thousand feet he takes his way,

Or as far into darkness from the cheerful light of day;

He is shut out from the sunlight in the glimmer of the lamps;

He is cut off from the sweet air in the sickly fumes and damps;

He must toil in cramped positions; he must take his life in his

hand;

For he works in deadly peril, that but few can understand;

But he does it all in silence and he seldom makes a kick,

Which is why I sing the praises of the man behind the pick.

He unlocks the belted portals of the mountains to the stores

Hid in nature's vast exchequer in her treasure house of ores;

He applies a key of dynamic, and the gates are backward rolled.

And the ancient rocks are riven to their secret heart of gold.

Things of comfort and of beauty, and of usefulness are mined,

By the brave, heroic fellow, who toils on all begrimed,

Trampled down and underpaid, works on without a pick; 
So I lift my hat in honor to the man behind the pick.

J.A. Edgerton

\section{A Colorado Heroine}

At times when freedom's sacred boon

Is dashed to earth by dastard hands;

When dear-bought liberties too soon

Are crushed by sacrilegious bands;

When justice weeps and takes her flight

From outraged temple, hearth and home;

And usurpation's murky night

Obscures the stars of heaven's dome;

The true heart leaps with swelling pride

At deed courageous, soul so grand -

A woman's will in danger tried,

A woman's brave and steady hand.

And, blazoned on the deathless page

Of history in lines of gold

She who to cowards flung the gauge

Shall read her name to millions told.

'Twas when that traitor to his vows

Of constitution, law and right,

Who shamed fair Colorado's brow

By deeds of brutal, tyrant might, 
The Peabody to scorn upheld,

At greed's relentless base behest,

Had raised his arm, and lawless, felled

The men who made the glowing West.

The troops, arrayed on Lucre's side,

Had occupied the mining town:

Proclaimed their orders far and wide

That court, and press, and speech must down,

And in they marched and seized the force

That got the Victor Record out:

They jailed them in the bull-pen coarse,

And thought them stilled beyond a doubt.

But all that night, with steel-set nerve,

A little woman, dauntless, worked,

Who loved the strikers' cause to serve,

And never task or danger shirked.

And when the morning tinged the east

With flaming shafts of sunrise gold,

Then only had her labors ceased -

The paper on the streets was sold.

And thus has Emma Langdon's name

Been placed with heroes of the past,

Wide given to the winds of fame 
While love of truth and hope shall last.

Till Labor, crawling like a slave,

Shall lift its form in giant might,

Shall break the death clamps of the grave

And lead mankind to joy and light.

Ida Crouch-Hazlett

\section{The Laborer}

The man who toils from morn to night

In rain or shine, in heat or cold,

With dangers everywhere in sight,

Who toils until he is too old,

And ever works,

He never shirks,

What is his boon, his compensation,

Of all the wealth of his creation?

With pick and shovel underground,

With dynamite he ventures bold

Far, far beneath all human sound

To break the rocks in search of gold.

No gold for him,

His share is slim,

It's just enough to check starvation

Enough to chain him to his station. 
He makes and guides the speedy train

From town to town, from land to land,

And rather dies in awful pain

In mishaps to leave his stand.

Oh human fools!

What willing tools!

But all you lack is education

To bring about your elevation.

He steers the ship with nerve and skill

Through weather-beaten seas,

He builds the palace, builds the mill

And all machineries.

He travels not.

Dwells in a hut;

He gets no time for recreation

Except when he has lost his station.

He battles for his country's sake

And dies for it with pride,

His little one he leaves at stake,

His wife, perhaps his bride

His country - his!

Ridiculous!

It is invention, base illusion

And intended for confusion. 
Awake, awake ye laboring men

And cease to suffer, cease to groan,

Emancipate, you must, you can,

Then go to battle with the drone;

You'll easily win

Their lines are thin -

Awake, awake to your salvation,

To justice and equalization.

\author{
Alfred Bem \\ Denver
}

July 25, 1903 


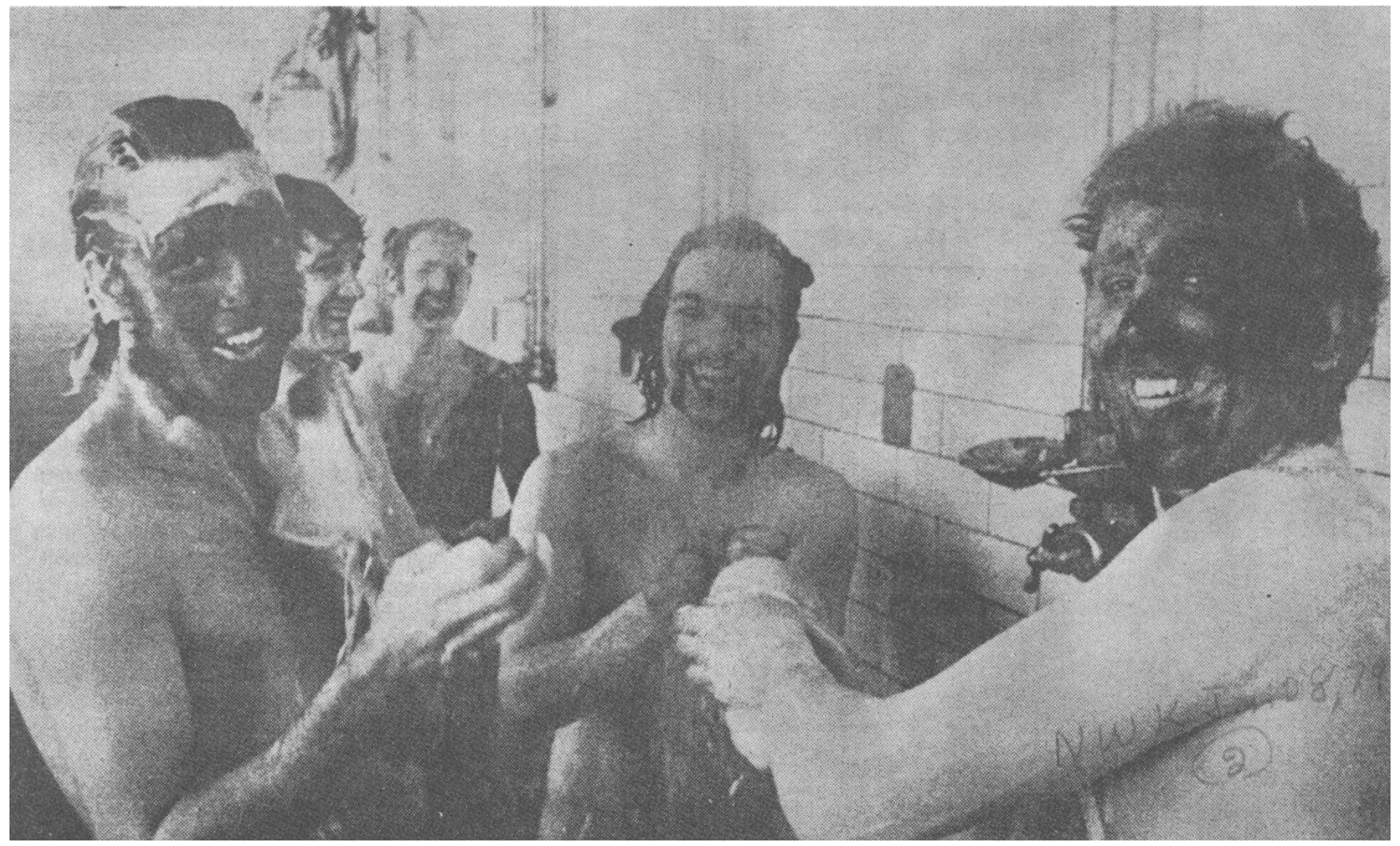

COAL MINERS, 1974

\section{Poems of Censure and Condemnation}

\section{The Curse of the Scab}

The man may betray his country

And his country's flag forsake,

And his name shall be accursed

And his life shall forfeit make;

The man may deny the Godhead

And the bigot's torch may gleam,

Yet the nation's flag is a painted rag

And the bigot's god a dream. 
The man, he may slay his brother,

And his brother's ghost forgive;

The man, he may rob the widow

And may restitute and live.

The woman may sell her body

And her guilt at last will pass,

But who will plead in his day of need

For the wretch that sells his class?

Yet his deed is of ancient usage

Of the code of the "Tooth and Claw,"

And the crime he does is legal

Behind the shield of the law;

And the faithless guards of freedom

And the priests of vested wrong,

And the shepherds who steep, nor feed the sheep,

Have sung him a soothing song.

But the new, true ethics whisper

And his fellows loudly cry:

"Make thou no pact with the spoiler,

For the time of times is nigh;

By the bootless trade of Esau,

By Iscariot's age-long ban,

As the man in pride from the beast will divide -

Go prove thyself the man!" 
The gods of the trial balance

Of Epah, and Ell, and Lakh;

They sit, in the gate of judgment,

On the souls that turn not back.

And may they curse with curses

Whose powers be strong or faint,

But into the breed of the traitorous deed

They strike the great scab faint.

That taint in the soul will fester

And burn like the serpent's bite,

Will itch in the listless morning

And throb through the restless night;

And, be it becloaked or naked,

All souls, as they pass, will feel

And smell the rot of the putrid spot

Of the scab that does not heal.

And never the ban of bishop,

Nor curse of a priest or pope,

Can drive so far from the guilty

The ghost of a sinner's hope,

For souls that are yet unshriven

Of murder and foul rapine,

By the lowest law their robes will draw 
And cry: "Unclean! Unclean!"

The soul with the scab shall wander

On deserts of scorching heat,

And the stones cry out in horror

And the hot sands loathe his feet;

Or, if in the covering darkness

His fearsome course he steer,

The myriad eyes of the silent skies

Will open and blink and peer.

The curse of the scab will follow

Like a wolf on a winter trail -

Stealthy and gaunt and eager -

'Til the hunted footsteps fail,

'Til under the gray-faced shadows,

While the frozen moon stands still,

It tears the throat with a snarling note;

It tears, but it does not kill.

The soul with the scab will feel it

Like a crawling, slimy snake,

That coils on the breast at midnight

When the underself shall wake;

That winds like a choking horror

Round bosom and neck and limb, 
'Till the cold beads start from brow and heart

And the white lip's quaking rim.

The soul with the scab will see it

In the cloudbank's scowling brow,

And his guilt will be told in thunder

That the traitorous heart will cow;

Will see it roost on his rooftree

Like a sullen brooding fate -

Like a raven of prey, whose croak will say,

"Too late! Too late! Too late!"

That curse will strike in the children

And its loathsome virus drip,

Will clot in the throat of the virgin

And crust on the suckling's lip,

With sighing and prayer and penance -

If penance and prayer be good -

But the taint still runs in the souls of the sons

To the third and the fourth of blood.

Webster Rogers

\section{Scab, Scab, Scab}

Altho' it's not my color, I'm feeling mighty blue, 
I have a lot of trouble, I'll tell it all to you.

I'm certainly clean disgusted with life and that's a fact,

Because my job is scabby and because my character is black.

My girl she took a notion against the scabby race.

She said if I would win her I'd have to change my place.

She said if she would wed me that she'd regret it bad,

Because I am an unfair man and working as a scab.

Chorus:

Scab, scab, scab, I wish my color would fade,

Scab, scab, scab, I wish my job was played,

Scab, scab, scab, I give my life for the maid.

I wish I was a union man instead of scab, scab, scab.

I had my white shirt laundered and gave my hair a cut,

I put my bran' new suit on - I certainly did loom up.

I started out to see her just twenty minutes of nine.

I had in mind the question to ask her to be mine,

And when I popped the question she said, "You made me sad

Do you know I can marry a union man? Do you think I'd look at a

scab?

My father is a W.F.M., my brother is the same,

My mother joined the auxiliary-I guess I'll not take your nam

Tune: "Coon, Coon, Coon"

Anonymous 


\section{The White Slave}

I.

Not bleeding 'neath the lash of Egypt's scorn,

Not in the dungeon, nor in galley chains,

Nor baited to the savage lions now,

Like those to Nero's bloody thirst consigned.

But look on him, the white slave of our time;

See on his face the centuries' stamp of crime.

II.

Ye see no chains, but yet more sharp than steel

Life's shackles cut into his tortured soul.

The white slave toils away his hopeless life

And dies like coral worm beneath the sea,

That palaces and gardens by his hands may grow,

While kingdoms rise and princes come and go.

III.

His masters revel while the white slave toils.

"Be ye contented," is his only cheer.

And when to God goes up a cry for help,

In vain he prays to him who dwells on high:

"O God of Plenty, art thou blind and deaf,

That to this lowly cry comes no relief?" 
IV.

His masters revel. Their remorse of soul

Is drowned in ruby wine, when tears should flow;

Lights of the ball room, softly pleading flutes.

What thoughts are lent for tales of man's distress?

Tell these of sorrow and they heed you not,

For splendor hides from them the cancerous blot.

V.

The masters revel. Countless thousands starve.

The white slave's cup of woe is surely full.

God of the wealthy, if thou be their God,

Cover thine eyes when this cup overflows,

For satan's realm makes not the whole of hell,

While sons of earth such fearful tales can tell.

VI.

The pulpits breathe forth libels on thy name;

Thou canst not be the God to whom they cry.

Thou wilt not stand for treason's earthly lords,

Nor see thy poor oppressed forever wronged.

Come quickly, lest thy teachings fade away,

And men forget thy mercies while they pray.

VII.

The black slave cried. His cry was not in vain; 
Prophets arose to sound the warning note.

The crisis came, and 'mid the clash of steel

From sable limbs the cruel fetters fell.

Great was the price, but not too great to pay,

That men might be redeemed from slavery's sway.

VIII.

Ye white slaves stand together, side by side,

And list in silent prayer the distant storm.

Though faint and far we catch its murmur now.

Prophetic ears cannot mistake the sound.

'Tis coming -- coming fast, this storm-cloud dark,

But those who revel neither see nor hark.

\section{The Eight Hour Day}

In Telluride the strike is still on

And on there it will stay

Until we get just what we want --

It is an eight-hour day.

Eight months we have been out on strike.

Up to the first of May,

And eight months more we'll stay on strike

Just for an eight-hour day. 
Though gatling guns and cannonade

Surround the town, oh, say,

I wonder what they'll do with them

After the eight-hour day!

They may deport us from our homes,

And tell us to stay away;

But then we'll not call off the strike

Until the eight-hour day.

We have labored hard for many a year,

We have labored night and day,

But when the people cast the votes,

It was for an eight-hour day.

They may confine some men in jail,

But they can't win out that way,

For our cause is just and we won't quit

Until the eight-hour day.

Now working men from Telluride,

I say just stay away;

The fight is yours as well as ours,

To get an eight-hour day.

ShortyP-------- 


\section{A Pariah's Prayer}

God of Justice, look down on the workmen,

Who've been toiling for thousands of years,

And for justice too often beseeching;

Will you nerve us to get it through the fears

Of legalized thieves, who still rob us

And cast us out on the world as tramps.

Far too long we've been pleading for mercy,

And it's time we should light up our lamps.

Whose rays will illumine the darkness

And enable the millions to see

That justice can be had for the taking,

And access to the land be made free;

Then the castle and hovel will vanish

And justice and reason command,

We'll have no more of the jailer or almshouse,

But fraternity and love through the land.

Go, ask the poor tenement housekeepers,

Or the "tramps" in the old, frosty streets,

What they think of Society's offsprings

Or the men out from prison one meets.

They will tell you that law is not justice

When framed by the plundering few; 
And the parties who prey on and jailed them

Are doing as the law bids them do.

I repeat that "law should be strangled,"

So that freedom will arise from its ruins,

Or some effort be made as determined

As was made by the plundered Bedouins

When the murderous, marauding invaders

Thought to force on that people their laws;

What lesson for us and our leaders

Was that blow for humanity's cause.

John F. Kearney

\section{Hobo Miner}

Dear old Arizon, I love thy rocky hills,

But how often have I cursed thee when I had to make long "drills"

Across the barren sandy wastes, and often do I think

Of the many rivers I have crossed and could not get a drink.

I could tell you "hard luck stories" of long trails and blistered

feet,

The memories of them make me dry, "Come on, Pard, it's my

treat."

What will I drink? you ask me. Why, I'll drink the same old thing

That puts us miners on the bum and keeps us on the "wing,"

That makes these "Birds of Passage," the flock grows every year, And increases still more rapidly since the advent of "scoop" beer. 
Arizona she's too hot, for some she is too dry;

Colorado, she's all right, but the altitude's too high;

So they high themselves away up north at the opening of the spring,

But the chilly northern winter's sure a swarm back here to bring.

They'll tell of the "tortilla route" and the "bread and milk line,"

too,

It's all they ever get to eat in Utah comin' thro'.

We call them "Hobo Miners," but this you will find true,

That these same miners are as good as any in the crew;

But their days are few and fleeting, they soon get the "wrinkles"

out,

They look around the country then to pick out some "star route."

There is always something wrong in every bloody camp,

They're sure to find some good excuse to keep them on the tramp,

If the "grub" and water are all right the air is never good;

He "couldn't work there if he would, and wouldn't if he could."

When he's in Arizona's heat, he'll dream of visions fair -

Of Colorado's snow-capped peaks and cool, pure mountain air;

So when in Colorado's snow a fierce desire will bum

For Arizona's sunny skies his heart will fondly yearn;

Away down South in "de vinter time" he longs to be again,

With a small road-stake he'll catch a brake upon a south-bound

train; 
In some warm stope it is his hope, to find a winter's home

In Arizona's copper camps - Globe, Bisbee or Jerome.

So thus with each succeeding year the feeling of unrest

And love for kindred spirits grows still stronger in his breast,

So when across the Great Divide he takes his last long "hike,"

We fondly trust he'll find a camp which "hobos" all will like -

All Union camps where the hours are short and the bosses are all

right,

Where they never change from day shift and have to work at

night,

Where the company furnishes gum clothes in all wet places there,

Where they don't "hold out his road tax" and the stopes all have

good air.

Where the summers never get too hot and the winters are not

cold,

Where everything goes in the "gobb" except the virgin gold,

Where there'll be no "hot sulphide stopes," they'll mine no

copper ore,

For there'll be naught heavenly lights on that bright golden shore.

At St. Peter's "hash foundry" is the end of his long route

He'll go out in the "jungles" there and take his last "boil out,"

So there we leave the wanderer in his bright Elysian home,

Where his "pie-card" never will run out and he'll care no more

to roam. 


\section{Aphorisms}

\section{Outpost Echoes}

Manhood knows no pattern.

Liberty does not study etiquette.

Hypocrisy oils the wheel of custom.

A radical does not live by words alone.

Privileges are for the rich; duties for the poor.

One great hope compensates for many little fears.

Roosevelt carries a revolver; does he contemplate suicide?

Poverty sanctifies property, and poverty results from theft.

The state argues by means of rapid fire guns and big bribes.

When the throne of God has fallen the other thrones begin to tremble.

At present woman's great privilege seems to be to love her 
chains.

The morrow holds in its womb what would be scorned and stoned

to-day.

Some men build monuments to liberty, while others become

liberty's living monuments.

The Liberal Party in England, like the Democratic Party in

America, is a condor with the voice of a nightingale.

He whose social nature has been ruined by studying the tricks of

trade will never understand what Socialism means.

Capitalism is singing a siren song into the ears of labor, the tune

of which is brotherhood. Labor is holding off; capitalism wants to

be the bigger brother.

Anonymous

\section{Bell Signals}

Agitation prevents stagnation.

The machine is the apprentice of yesterday, the journeyman of today.

A rich sermon is poor satisfaction to an empty stomach. 
If the producer is not entitled to the equivalent of that which he

produces, who is?

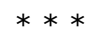

A labor organization without political purpose is as meat with the nutriment extracted.

The supervision of industry by the producers will obliterate race

prejudice and imaginary boundary lines.

A soldier commits wholesale murder for $\$ 13$ a month. The

working class abets the crime by upholding the system that

permits it.

Colleges and universities are the modern scab hatcheries where

the Farleys secure strikebreaking recruits. It is to Rockefeller's

interest to maintain such institutions, at the people's expense.

When the working class is sufficiently well-organized to control

the economic power - the means of life - legislatures and courts,

militia and police, will be expensive luxuries for capitalists.

William D. Haywood

\section{$(\mathrm{Cc})$ EY-NC-NO}

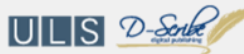

This work is licensed under a Creative Commons Attribution-Noncommercial-No Derivative Works 3.0 United States License.

This journal is published by the University Library System of the University of Pittsburgh as part of its D-Scribe Digital Publishing Program, and is cosponsored by the University of Pittsburgh Press. 